\title{
Study Site Role
}

National Cancer Institute

\section{Source}

National Cancer Institute. Study Site Role. NCI Thesaurus. Code C70781.

A designation of responsibilities of a clinical site in conducting a particular clinical study. 